\title{
Genetic Relationships Between Cercospora kikuchii Populations from South America and Japan
}

\author{
I. Imazaki, Y. Homma, M. Kato, S. Vallone, J. T. Yorinori, A. A. Henning, H. Iizumi, and S. Koizumi
}

First and seventh authors: National Agricultural Research Center, Tsukuba, Ibaraki 305-8666, Japan; second and third authors: Japan International Research Center for Agricultural Sciences, Tsukuba, Ibaraki 305-8686, Japan; fourth author: INTA EEA Marcos Juárez, Marcos Juárez, Córdoba 2580, Argentina; fifth and sixth authors: Embrapa Soja, Londrina, Paraná 86001-970, Brazil; and eighth author: National Agricultural Research Center for Tohoku Region, Daisen, Akita 014-0102, Japan. Accepted for publication 6 April 2006.

\begin{abstract}
Imazaki, I., Homma, Y., Kato, M., Vallone, S., Yorinori, J. T., Henning, A. A., Iizumi, H., and Koizumi, S. 2006. Genetic relationships between Cercospora kikuchii populations in South America and Japan. Phytopathology 96:1000-1008.

A collection 160 isolates of Cercospora kikuchii was made from South America and 245 from Japan. DNA fingerprint patterns were analyzed based on amplified fragment length polymorphism among the sample isolates, dividing the isolates into seven lineages (I to VII). Partial nucleotide sequence analyses of the $\beta$-tubulin gene supported this division into seven

lineages. Lineages I and III commonly existed in South America and Japan. In all, 136 of the 160 isolates from South America and 223 of the 245 isolates from Japan belonged to lineage I, indicating that lineage I was the major lineage in each area; 5 isolates from South America and 8 isolates from Japan belonged to lineage III. Lineages II (12 isolates) and IV ( 2 isolates) were specific to Japan and lineages V ( 3 isolates), VI (1 isolate), and VII (15 isolates) specifically existed in South America. These results suggest that the population genetic structure of $C$. kikuchii was different between South America and Japan, but the dominance of lineage I was common between the two areas.
\end{abstract}

As plant hosts have been redistributed, fungal pathogens also often have been moved to new areas (7). These events cause changes in the gene and genotype frequencies among geographical populations of each pathogen. Intercontinental-scale samplings of several fungal pathogens have provided new insights into their epidemiology and evolutionary history $(9,11,12,15$, $28,35,38,43,44,48,66)$. An understanding of population structure on a continental scale is important for developing adequate plant quarantine systems.

Cercospora kikuchii (Matsumoto \& Tomoyasu) Gardner causes Cercospora blight, leaf spot, and purple seed stain of soybean (50). The fungus is agriculturally and economically important wherever soybean is cultivated in the world. Purple seed stain reduces seedling establishment in the field by reducing germination rates $(41,62)$ and increasing the incidence of disease in seedlings (32), as well as reducing commercial value. It also reduces carbohydrate content in seed (29). Purple seed stain is conspicuous and easily distinguished, but the fungus also has been isolated from seeds that show no visible symptoms (62).

Thiophanate-methyl, a benzimidazole fungicide, has been applied for the control of soybean purple stain since 1971 in Japan. Benzimidazole typically stops the growth of fungal pathogens by interfering with microtubule assembly $(17,18)$, and application of the fungicide during reproductive growth of soybean apparently controls purple stain $(39,49,57)$. However, resistance to thiophanate-methyl has been detected since the late $1980 \mathrm{~s}$ among C. kikuchii isolates (49), causing serious problems in soy-

Corresponding author: I. Imazaki; E-mail address: iiori@affrc.go.jp

* The $\boldsymbol{e}$-Xtra logo stands for "electronic extra" and indicates that the online version contains supplemental material not included in the print edition. Three tables and one figure appear online.

DOI: 10.1094/PHYTO-96-1000

(C) 2006 The American Phytopathological Society bean production in Japan. The resistance results from a singlestep change in the $\beta$-tubulin gene, causing amino acid substitution of glutamic acid with alanine at position $198(22,40)$. This type of change leads to high resistance to benzimidazole fungicides in vitro $(24,30)$, which also has been verified in field evaluations of disease incidence on soybean plants treated with thiophanatemethyl $(21,49)$.

Amplified fragment length polymorphism (AFLP) can generate a potentially unlimited number of molecular markers with multiple polymerase chain reaction (PCR) primer pair combinations or sets of restriction enzymes (59). In addition, high reproducibility of the markers was shown $(3,4,25,26,33)$. Because little was known about molecular markers in $C$. kikuchii except for AFLP (60), we used the technique and found that the Japanese population of the pathogen was composed of four AFLP lineages (I to IV), and showed that incidence of thiophanate-methyl resistance occurred within lineage I, the largest of the four lineages $(22,23)$.

Soybean was domesticated in northeastern China during the Shang dynasty over 3,000 years ago $(20,46)$ and was estimated to have been grown in Japan for approximately 2,000 years (13, 19,56). Beginning in 1765 , it was introduced into the United States, mostly from Japan and China, and has become a widely planted major crop $(20,42,45)$. The early period of introduction of soybean into South America was the beginning of the 20th century. Soybean was introduced from Japan to Brazil by immigrant farmers, but did not become an important crop (53). However, introduction of soybean into South America in the middle of the 20th century from the United States resulted in a rapid increase in production $(5,53,61,63)$.

We hypothesized that $C$. kikuchii was directly or indirectly introduced into South America from eastern Asia on seed, because purple stain is a typical seedborne disease (50). To test the hypothesis, we collected C. kikuchii isolates from South America and investigated the genetic relationships between the South American isolates and the Japanese isolates, which were collected 
in the previous study (22), by DNA fingerprinting based on AFLP and nucleotide sequencing of the $\beta$-tubulin gene.

\section{MATERIALS AND METHODS}

Fungal strains. In all, 160 isolates of C. kikuchii from 26 soybean cultivars (A5777 RG, A5901 RG, A6040 RG, A6355 RG, A6445 RG, A800 RG, A8100 RG, A9000 RG, ADM50048 RR, AW5522 RR, AW5581 RR, DM5800 RR, J024992, Maxisoy 8080 RR, Munasqa RR, Nueva Maria 55 RR, Qualia RR, Rafaela 58 RR, RAR516, RAR518, RAR602, RAR626, RAR701, RAR703, RAR709, and TJ2055 RR) grown in two Argentine provinces (Córdoba and Santa Fe) and from 4 cultivars (CARIRI RCH, PATI, BRS 133, and BR 95 3412) grown in four Brazilian States (Goias, Maranhäo, Mato Grosso, and Paraná) between 1996 and 2004 (148 of the 160 isolates were obtained from plants grown in 2004) were tested. The host soybean cultivars of 6 of the 160 isolates could not be identified.

Of the 247 isolates of the pathogen used in the previous study (22), 245 isolates from 16 soybean cultivars (Aodaizu, Aomorifukumaru, Enrei, Fukuyutaka, Murayutaka, Okushirome, Oosuzu, Ryuhou, Suzukari, Suzunone, Tachinagaha, Tachiyutaka, Tamahomare, Tanrei, Touhoku 146, and Wasesuzunari) grown in 15 Japanese prefectures (Akita, Aomori, Ehime, Ibaraki, Iwate, Miyagi, Niigata, Nagano, Okayama, Oita, Saitama, Saga, Tottori, Toyama, and Yamagata) between 2001 and 2003 were tested.

Assay for sensitivity to thiophanate-methyl. The South American isolates were tested for sensitivity to thiophanate-methyl by measuring the minimum inhibitory concentration (47). The isolates were grown on potato dextrose agar amended with thiophanate-methyl at $0,1.6,6.3,25,100,400$, and 1,600 $\mu \mathrm{g} / \mathrm{ml}$. Two replicates of each fungicide concentration for each isolate were used. After 5 days of incubation at $25^{\circ} \mathrm{C}$ in the dark, fungicide sensitivity was assessed.

The results of the previous study (22) for the sensitivity of the Japanese isolates, classifying all of the isolates into two distinct levels (sensitive and highly resistant), were used. Sensitive isolates could not grow on media containing thiophanate-methyl at only $1.56 \mu \mathrm{g} / \mathrm{ml}$. In contrast, highly resistant isolates could grow on media containing at least $1,600 \mu \mathrm{g} / \mathrm{ml}$.

DNA extraction. The South American isolates were grown on potato dextrose agar at $25^{\circ} \mathrm{C}$ for 3 weeks to extract total DNA. After flooding the resulting mycelia with sterilized water, the surface of the culture was scrubbed with small sterilized wooden sticks. Then, the aerial hyphae suspended in the sterilized water was transferred from the petri dishes into potato dextrose broth in 200-ml Erlenmeyer flasks, and the broth was cultured at $25^{\circ} \mathrm{C}$ for 2 days on an orbital shaker (at $60 \mathrm{rpm}$ ). Total DNA samples were prepared from the resulting mycelia as described by Adachi et al. (1). The total DNA of the Japanese isolates was extracted as described in the previous study (22).

AFLP analyses. AFLP analysis was performed as described by Imazaki et al. (22). Total DNA was digested with EcoRI and MseI and ligated with AFLP adaptors. The ligated fragments were used as templates for nonselective PCR amplification with the primers EcoRI-0 (5'-GACTGCGTACCAATTC-3') and MseI-0 (5'-GATGAGTCCTGAGTAA-3'). The PCR profile was as follows: an initial preheating at $94^{\circ} \mathrm{C}$ for $2 \mathrm{~min}$; followed by 20 cycles of denaturation at $94^{\circ} \mathrm{C}$ for $30 \mathrm{~s}$, annealing at $56^{\circ} \mathrm{C}$ for $1 \mathrm{~min}$, and extension at $72^{\circ} \mathrm{C}$ for $1 \mathrm{~min}$; with a final extension at $72^{\circ} \mathrm{C}$ for $10 \mathrm{~min}$. The reaction solution was used for selective PCR using the following profile: denaturation at $94^{\circ} \mathrm{C}$ for $30 \mathrm{~s}$, annealing at $68^{\circ} \mathrm{C}$ for $30 \mathrm{~s}$, and extension at $72^{\circ} \mathrm{C}$ for $1 \mathrm{~min}$; followed by 17 cycles of denaturation at $94^{\circ} \mathrm{C}$ for $30 \mathrm{~s}$, annealing for $30 \mathrm{~s}$ (the annealing temperature in the first cycle was $68^{\circ} \mathrm{C}$ and subsequently was reduced by $0.7^{\circ} \mathrm{C}$ each cycle for the next 16 cycles), and extension at $72^{\circ} \mathrm{C}$ for $1 \mathrm{~min}$; followed by 23 cycles of denaturation at $94^{\circ} \mathrm{C}$ for $30 \mathrm{~s}$, annealing at $56^{\circ} \mathrm{C}$ for $30 \mathrm{~min}$, and extension at $72^{\circ} \mathrm{C}$ for $1 \mathrm{~min}$; with a final extension at $72^{\circ} \mathrm{C}$ for $10 \mathrm{~min}$. Amplified fragments were separated in polyacrylamide gels with $1 \times$ Tris glycine buffer. After staining the gels with Vistra Green (Amersham Biosciences, Piscataway, NJ), images of the DNA fingerprint patterns were scanned using an FxProPlus Molecular Imager (Bio-Rad Laboratories, Hercules, CA).

The primer pair EcoRI-A (5'-GACTGCGTACCAATTCA3')/MseI-CA (5'-GATGAGTCCTGAGTAACA-3') was used for genetic analysis of Cercospora spp. (60). This primer pair was tested for the selective PCR amplification using three C. kikuchii isolates (JC198, JC175, and S411) in addition to 16 randomly chosen primer pairs (EcoRI-A/MseI-GT, A/TG, A/GG, A/TC, A/TA, C/TC, C/GA, C/TG, T/AG, T/GA, T/TC, T/TG, T/GC, T/TA, T/TT, and T/GC). On the basis of number of polymorphic fragments, the primer pairs EcoRI-A/MseI-CA and EcoRI-C (5'GATGAGTCCTGAGTAATC-3')/MseI-TC (5'-GATGAGTCCTGAGTAATC-3') were selected. Total DNA of seven randomly chosen isolates (JC002, JC010, JC020, JC083, JC085, JC089, and S281) was extracted twice from independent cultures and was used for AFLP analyses with the primer pairs EcoRI-A/MseI-CA and EcoRI-C/MseI-TC to verify reproducibility of results.

AFLP data analyses. In the previous study (22), the AFLP fingerprints of the Japanese isolates generated by the primer pair EcoRI-C/MseI-TC were obtained, and the data also were used in the present study. The AFLP fingerprints of South American isolates generated by the primer pairs EcoRI-A/MseI-CA and EcoRI-C/MseI-TC and those of Japanese isolates generated by the primer pair EcoRI-A/MseI-CA were obtained in the present study.

The presence and absence of major AFLP bands were scored manually as " 1 " and " 0 ," respectively, assuming that bands with the same molecular size in different individuals were homologous. The Windist program of Winboot (64) was used to calculate Dice coefficients $\left(D_{S}\right)(54)$ among all pairs of isolates tested using the formula $D_{S}=2 N_{x y} /\left(2 N_{x y}+N_{x}+N_{y}\right)$, where $N_{x y}$ is the number of markers shared by isolates $X$ and $Y, N_{x}$ is the number of markers specifically amplified for isolate $X$, and $N_{y}$ is the number of markers specifically amplified for isolate $Y$. A phenogram from $D_{S}$ was constructed by means of the unweighted pairgroup method with arithmetic mean (UPGMA) clustering (54) using the MEGA3 software (31). Bootstrap values (10) were determined using Winboot.

Diversity indices were calculated based on lineage and genotype data using Shannon-Weaver's diversity index $(H w)(6,34,51)$ and Simpson's diversity index $(\lambda)(52)$. The formulae of these indices are as follows: $H w=-\Sigma_{i}\left(\left[n_{i} / N\right] \times \ln \left[n_{i} / N\right]\right)$ and $\lambda=1-$ $\Sigma_{i}\left(\left[n_{i}\left(n_{i}-1\right)\right] /[N(N-1)]\right.$, where $n_{i}$ is the number of individuals in the $i$ th lineage (genotype) and $N$ is the total number of individuals. The sampling variances of $H w$ and $\lambda$ were obtained by $V(H w)=\left(\Sigma_{i}\left[n_{i} \times \ln ^{2} n_{i}\right]-\sum_{i}\left[n_{i} \times \ln n_{i}\right]^{2} / N\right) / N^{2}+(g-1) / 2 N^{2}$, where $g$ is the number of lineages (genotypes), and $\mathrm{V}(\lambda)=(4 N[N-$ $1][N-2] \times \Sigma_{i}\left[n_{i} / N\right]^{3}+2 N[N-1] \times \Sigma_{i}\left[n_{i} / N\right]^{2}-2 N[N-1][2 N-$ $\left.3]\left[\sum_{i}\left(n_{i} / N\right)^{2}\right]^{2}\right) /(N[N-1])^{2}$, respectively. Then, the lineage and genotype diversities of pairs of samples were compared using Student's $t$ test.

Partial nucleotide sequences of the $\beta$-tubulin gene from C. kikuchii. Highly conserved regions of the $\beta$-tubulin gene nucleotide sequences were identified in several fungi: Aspergillus flavus (accession no. M38265), Botrytis cinerea (Z69263), Colletotrichum gloeosporioides (U14138), Gibberella fujikuroi (U27303), Leptosphaeria maculans (AF257329), Neurospora crassa (M13630), Pestalotiopsis microspora (AF115396), and Venturia inaequalis (M97951). On this basis, the PCR primers tub-f1 (5'-GGTCATTACACTGAGGGTGC-3') and tub-r1 (5'GACAAGATCGTTCATGTTGGACTC-3') were designed (22). PCR amplification was performed with these primers in a $100-\mu \mathrm{l}$ volume containing $100 \mathrm{ng}$ of total DNA (template), $0.4 \mu \mathrm{M}$ each primer, 2.5 U of Takara Taq polymerase, 1× Takara Taq poly- 
merase buffer, and $0.2 \mathrm{mM}$ each dNTP. The PCR profile was as follows: an initial preheating at $94^{\circ} \mathrm{C}$ for $2 \mathrm{~min}$; followed by 30 cycles of denaturation at $94^{\circ} \mathrm{C}$ for $30 \mathrm{~s}$, annealing at $56^{\circ} \mathrm{C}$ for $30 \mathrm{~s}$, and extension at $72^{\circ} \mathrm{C}$ for $1 \mathrm{~min}$; with a final extension at $72^{\circ} \mathrm{C}$ for $10 \mathrm{~min}$. To confirm the amplification, $5 \mu \mathrm{l}$ of each sample was separated by electrophoresis in $0.8 \%$ (wt/vol) agarose gels. The PCR products were purified using the QIAquick PCR Purification Kit (Qiagen, Valencia, CA) following the manufacturer's directions. The nucleotide sequences of the purified fragments were determined directly using the BigDye Terminator Cycle Sequencing Kit (version 1.1) on an automated DNA sequencer (ABI Prism 3100 Genetic Analyzer; Applied Biosystems, Foster City, CA).
In the previous study (22), the nucleotide sequences of the $\beta$ tubulin gene of the 12 isolates (21S-17, JC043, JC044, JC084, JC092, JC121, JC124, JC203, JC209, JC223, S381, and TI23) were identified, and the data also were used in the present study. The nucleotide sequences of 44 additional $C$. kikuchii isolates were obtained in the present study.

The partial sequences of the $\beta$-tubulin gene were aligned using the ClustalW software (version 1.83) $(16,58)$, and phylogenetic relationships were revealed based on the nucleotide sequence alignment of the $\beta$-tubulin genes among the $C$. kikuchii isolates using the MEGA3 software. A neighbor-joining tree was constructed based on distances determined by the method of Jukes and Cantor (27) using 1,000 bootstrap replicates.

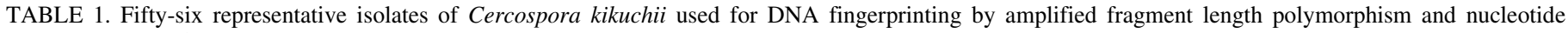
sequencing of the $\beta$-tubulin gene ${ }^{\mathrm{a}}$

\begin{tabular}{|c|c|c|c|c|}
\hline Isolate & Location & Year & Host cultivar & Host tissue \\
\hline $40 / 01$ & Londorina, Paraná, Brazil & 2001 & BRS133 & Stem \\
\hline $44 / 01$ & Sapezal, Mato Grosso, Brazil & 2001 & BR 953412 & Leaf \\
\hline $23 / 98$ & Nova Mutum, Mato Grosso, Brazil & 1998 & ni & ni \\
\hline $77 / 96$ & Brazil & 1996 & ni & ni \\
\hline $\mathrm{AC} 001$ & Marcos Juárez, Córdoba, Argentina & 2004 & A5777 RG & Seed \\
\hline $\mathrm{AC} 002$ & Marcos Juárez, Córdoba, Argentina & 2005 & A5777 RG & Seed \\
\hline $\mathrm{AC} 003$ & Marcos Juárez, Córdoba, Argentina & 2006 & A5777 RG & Seed \\
\hline $\mathrm{AC} 004$ & Marcos Juárez, Córdoba, Argentina & 2007 & A5777 RG & Seed \\
\hline $\mathrm{AC} 010$ & Marcos Juárez, Córdoba, Argentina & 2004 & RAR703 & Seed \\
\hline $\mathrm{AC} 026$ & Marcos Juárez, Córdoba, Argentina & 2004 & DM5800 RR & Seed \\
\hline $\mathrm{AC} 028$ & Marcos Juárez, Córdoba, Argentina & 2004 & DM5800 RR & Seed \\
\hline $\mathrm{AC} 031$ & Marcos Juárez, Córdoba, Argentina & 2004 & RAR602 & Seed \\
\hline $\mathrm{AC} 035$ & Marcos Juárez, Córdoba, Argentina & 2004 & A6445 RG & Seed \\
\hline $\mathrm{AC} 038$ & Marcos Juárez, Córdoba, Argentina & 2004 & A6445 RG & Seed \\
\hline $\mathrm{AC} 042$ & Marcos Juárez, Córdoba, Argentina & 2004 & MUNASQA RR & Seed \\
\hline $\mathrm{AC} 047$ & Marcos Juárez, Córdoba, Argentina & 2004 & RAFAELA58 RR & Seed \\
\hline $\mathrm{AC} 048$ & Marcos Juárez, Córdoba, Argentina & 2004 & RAFAELA58 RR & Seed \\
\hline $\mathrm{AC} 053$ & Marcos Juárez, Córdoba, Argentina & 2004 & NUEVA MARIA RR & Seed \\
\hline $\mathrm{AC} 055$ & Marcos Juárez, Córdoba, Argentina & 2004 & NUEVA MARIA RR & Seed \\
\hline AC069 & Saira, Córdoba, Argentina & 2004 & ADM50048 RR & Seed \\
\hline $\mathrm{AC} 070$ & Saira, Córdoba, Argentina & 2003 & ADM50048 RR & Seed \\
\hline $\mathrm{AC} 076$ & Saira, Córdoba, Argentina & 2003 & ADM50048 RR & Seed \\
\hline AC081 & Saira, Córdoba, Argentina & 2003 & ADM50048 RR & Seed \\
\hline AC086 & Corral de Bustos, Córdoba, Argentina & 2004 & RAR518 & Seed \\
\hline AC090 & Corral de Bustos, Córdoba, Argentina & 2004 & RAR518 & Seed \\
\hline $\mathrm{AC} 094$ & Corral de Bustos, Córdoba, Argentina & 2004 & RAR518 & Seed \\
\hline AC096 & Corral de Bustos, Córdoba, Argentina & 2004 & RAR518 & Seed \\
\hline $\mathrm{AC} 107$ & Tortugas, Santa Fe, Argentina & 2004 & RAR516 & Seed \\
\hline $\mathrm{AC} 115$ & Tortugas, Santa Fe, Argentina & 2004 & MAXISOY8080 RR & Seed \\
\hline $\mathrm{AC} 128$ & Caferata, Santa Fe, Argentina & 2004 & A9000RG & Seed \\
\hline $\mathrm{AC} 144$ & Tortugas, Santa Fe, Argentina & 2004 & TJ2055RR & Seed \\
\hline $21 S-11$ & Saga-gun, Saga, Japan & 2001 & Fukuyutaka & Seed \\
\hline $21 S-13$ & Saga-gun, Saga, Japan & 2001 & Fukuyutaka & Seed \\
\hline $21 S-16$ & Saga-gun, Saga, Japan & 2001 & Fukuyutaka & Seed \\
\hline $21 \mathrm{~S}-17$ & Saga-gun, Saga, Japan & 2001 & Fukuyutaka & Seed \\
\hline $\mathrm{JC} 043$ & Hirosaki, Aomori, Japan & 2002 & Suzunone & Seed \\
\hline $\mathrm{JC} 044$ & Hirosaki, Aomori, Japan & 2002 & Suzunone & Seed \\
\hline $\mathrm{JC} 084$ & Daisen, Akita, Japan & 2002 & Ryuho & Seed \\
\hline JC092 & Tsuruoka, Yamagata, Japan & 2001 & Ryuho & Seed \\
\hline JC096 & Tsuruoka, Yamagata, Japan & 2001 & Ryuho & Seed \\
\hline $\mathrm{JC} 121$ & Tsukubamirai, Ibaraki, Japan & 2003 & Tachinagaha & Seed \\
\hline $\mathrm{JC} 124$ & Kumagaya, Saitama, Japan & 2002 & Tachinagaha & Seed \\
\hline JC164 & Toyama, Toyama, Japan & 2002 & Enrei & Seed \\
\hline $\mathrm{JC} 165$ & Toyama, Toyama, Japan & 2002 & Enrei & Seed \\
\hline JC203 & Akaiwa, Okayama, Japan & 2002 & Aodaizu & Seed \\
\hline JC209 & Imabari, Ehime, Japan & 2001 & Tamahomare & Seed \\
\hline $\mathrm{JC} 210$ & Imabari, Ehime, Japan & 2001 & Tamahomare & Seed \\
\hline $\mathrm{JC} 221$ & Saijo, Ehime, Japan & 2003 & Tamahomare & Seed \\
\hline $\mathrm{JC} 223$ & Saijo, Ehime, Japan & 2003 & Tamahomare & Seed \\
\hline S211 & Niigata, Niigata, Japan & 2002 & Enrei & Seed \\
\hline $\mathrm{S} 281$ & Kamo, Niigata, Japan & 2002 & Enrei & Seed \\
\hline S361 & Nagaoka, Niigata, Japan & 2002 & Enrei & Seed \\
\hline S381 & Ojiya, Niigata, Japan & 2002 & Enrei & Seed \\
\hline S481 & Minamiuonuma-gun, Niigata, Japan & 2002 & Enrei & Seed \\
\hline TI12 & Hirosaki, Aomori, Japan & 2001 & Tohoku146 & Seed \\
\hline TI23 & Higashitsugaru-gun, Aomori, Japan & 2002 & Osuzu & Seed \\
\hline
\end{tabular}

a The 56 isolates were sensitive to thiophanate-methyl, except for isolate JC203; ni = not identified. 


\section{RESULTS}

Genetic relationships among the $\boldsymbol{C}$. kikuchii isolates. We used a total of 405 C. kikuchii isolates for the AFLP analyses. Each of the AFLP primer pairs generated nearly identical fingerprint patterns from 359 isolates. We randomly chose 10 of the 359 closely related isolates and the remaining 46 isolates that exhibited infrequent fingerprint patterns as a set of representatives for our calculation of genetic similarity based on AFLP and for

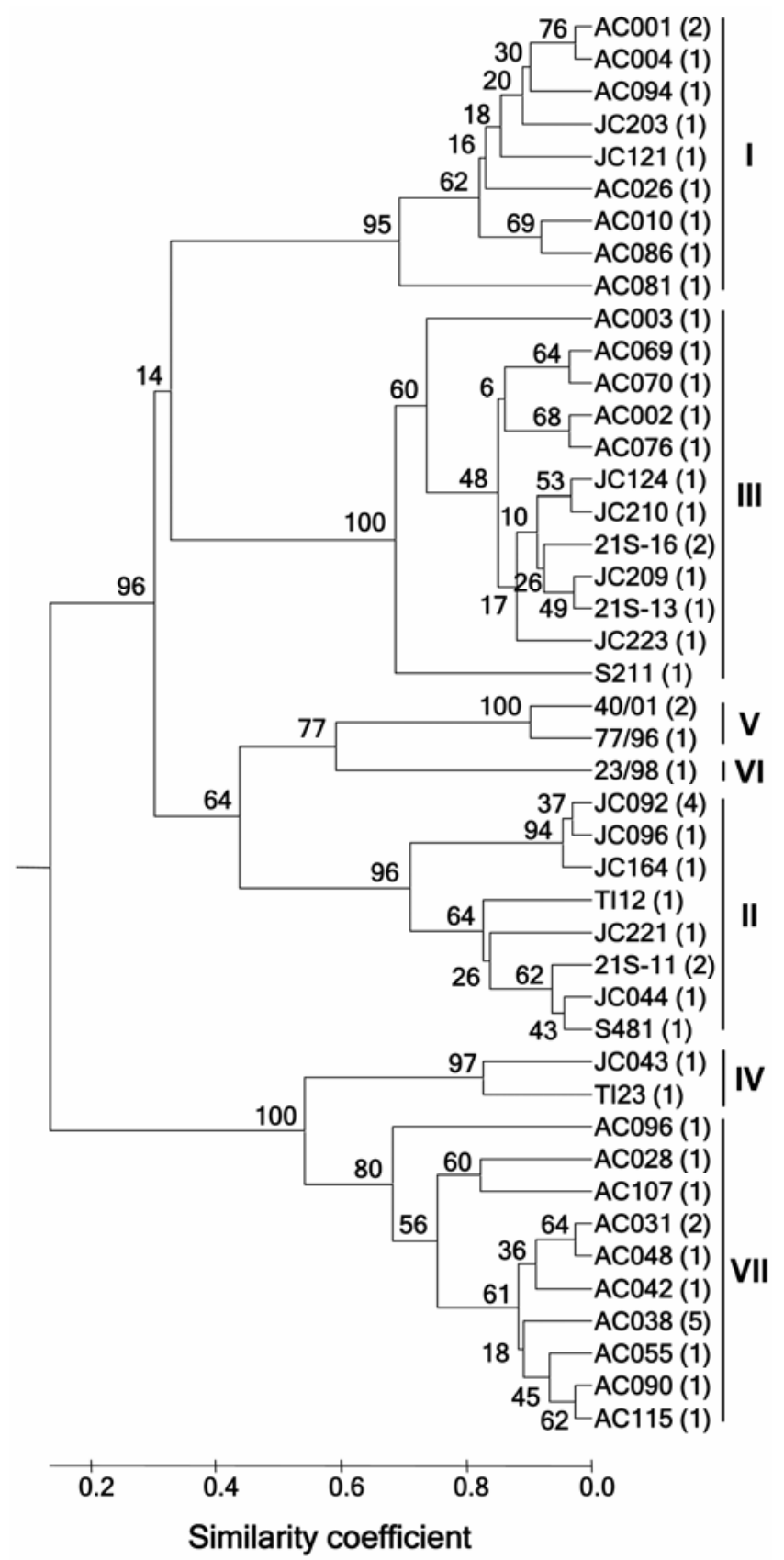

Fig. 1. Phenogram showing levels of similarity among the 56 representative isolates of Cercospora kikuchii. Similarity coefficients were calculated from genotype data based on amplified fragment length polymorphism (AFLP) fingerprint patterns. The phenogram was constructed from the similarity coefficient by means of unweighted pairgroup method with arithmetic mean clustering (55). Scale bar indicates similarity between the clusters. Values on the branches of the phenogram represent the percentage appearance of a given branch in 1,000 bootstrap replications (10). Numbers in parentheses indicate the number of isolates belonging to each genotype. Isolate AC001 had the same AFLP fingerprint patterns as JC084; 21S-16 as 21S-17; 40/01 as 44/01; JC092 as S281, JC165, and S381; 21S-11 as S361; AC031 as AC035; AC038 as $\mathrm{AC} 047, \mathrm{AC} 053, \mathrm{AC} 128$, and $\mathrm{AC} 144$

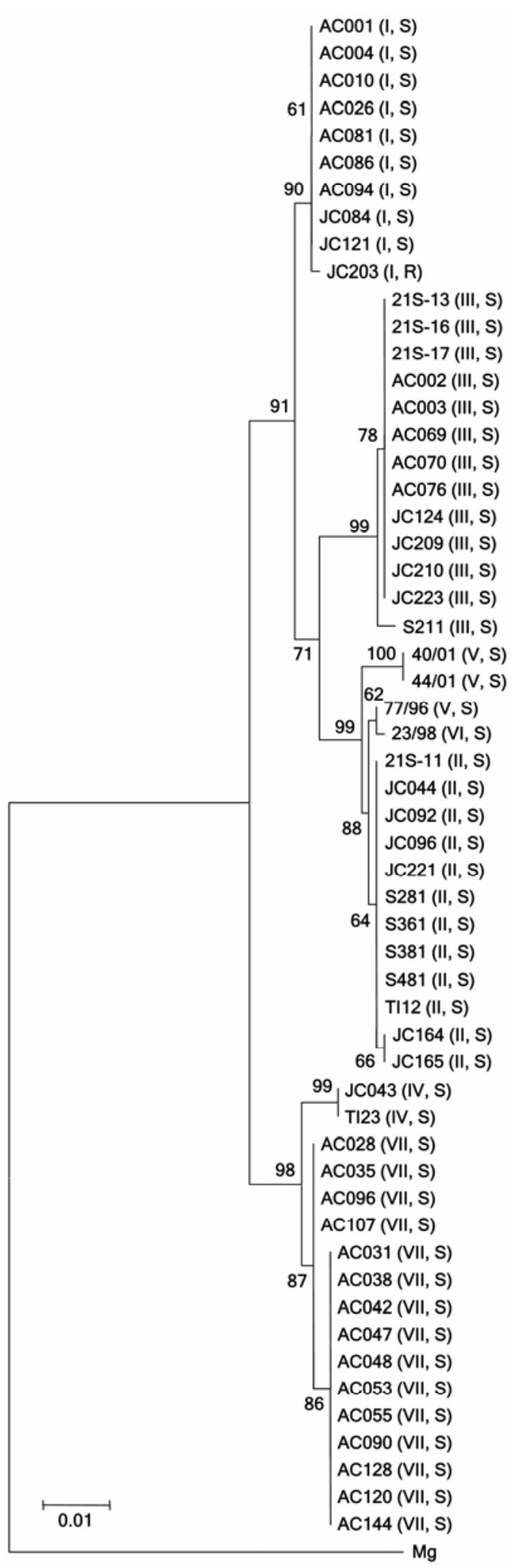

Fig. 2. Neighbor-joining tree derived from partial nucleotide sequences of the $\beta$-tubulin gene of the 56 representative isolates of Cercospora kikuchii. Distances were determined by the Juke-Cantor parameter (27). Scale bar indicates a distance of 0.01 (one base change per 100 nucleotide positions). Values on the branches of the tree represent the percent appearance of a given branch in 1,000 bootstrap replications. The nucleotide sequences of the $\beta$-tubulin genes of the $C$. kikuchii isolates are available in the DDBJ/EMBL/GenBank databases (accession nos. AB214511 to AB 214515; AB240216 to AB240222; AB253983 to AB254026). The $\beta$-tubulin gene of Mycosphaerella graminicola (Mg; accession no. AY547264) was used as an outgroup. Thiophanate-methyl sensitivity and amplified fragment length polymorphism lineage are indicated in parentheses. 
the phylogenetic analysis of the $\beta$-tubulin gene (Table 1). For analysis of the 56 representative isolates, we used a total of 93 scorable AFLP markers, ranging in size from 30 to $170 \mathrm{bp}$ (EcoRI-A/MseI-CA) and 30 to 160 bp (EcoRI-C/MseI-TC), of which 92 were polymorphic. As a result, we identified 44 unique AFLP genotypes. UPGMA clustering of pairwise similarities in the 44 genotypes revealed that the South American isolates were resolved into five AFLP groups, of which two corresponded to previously designated lineages (I and III) among Japanese isolates and three were new lineages (Fig. 1). We designated the newly identified groups as lineages V, VI, and VII. All genotypes within each lineage were joined by a single node at 0.69 (lineage I), 0.71 (lineage II), 0.68 (lineage III), 0.83 (lineage IV), 0.90 (lineage V), and 0.68 (lineage VII) similarity levels (Fig. 1). We observed significant bootstrap values, ranging from 80 to $100 \%$, for these lineages.

We compared nucleotide sequences ( $834 \mathrm{bp}$ ) amplified by PCR with primers tub-f1 and tub-r1 among the 56 representative isolates. The amplified DNA encoded 278 amino acids, from position 121 to position 398 of $\beta$-tubulin, with no introns, showing sequence similarity with the $\beta$-tubulin genes of other fungi. Among the 56 isolates, we found 7 new distinct forms of nucleotide sequences, which are represented by the isolates JC164, 23/98, 77/96, 40/01, S211, AC028, and AC031 (accession nos. $\mathrm{AB} 240216$ to $\mathrm{AB} 240222$ ), in addition to 5 previously registered forms, which are represented by the isolates JC203, JC084, JC092, JC209, and JC043 (AB214511 to AB214515). The nucleotide sequences of the other isolates also are available (accession nos. AB253983 to AB254026). These nucleotide sequences were resolved into distinct groups that were correlated with the AFLP lineages (Fig. 2). These results supported our separation of the sample population into seven lineages.

No South American isolates could grow on media containing thiophanate-methyl at only $1.6 \mu \mathrm{g} / \mathrm{ml}$, indicating that they were sensitive to the fungicide. As expected from the results with C. kikuchii (22) and other fungi $(2,30,65)$, the South American isolates shown in Figure 2 had the sequence GAG, which encodes glutamic acid, at codon 198 in the $\beta$-tubulin gene. In contrast, the resistant isolate JC203 shown in Figure 2 had a one-step change to GCG at codon 198, which encodes alanine.

The 10 isolates (AC001, AC004, AC010, AC026, AC081, JC084, AC086, AC094, JC121, and JC203) that we used as representatives of the 359 isolates with similar fingerprint patterns were clustered in lineage I (Figs. 1 and 2), indicating that these 359 isolates belonged to lineage I (Table 2). We also analyzed the genetic similarities among the 359 lineage I isolates using the same AFLP primer pairs. Using a total of 48 scorable bands ranging in size from 100 to $350 \mathrm{bp}$ (EcoRI-A/MseI-CA) and from 130 to 290 bp (EcoRI-C/MseI-TC), of which 38 were polymorphic, we divided the sample into 123 genotypes. However, because these genotypes are closely related (mean of the similarity coefficients among the 123 genotypes was 0.87), relatedness among the most 123 genotypes based on UPGMA clustering could not be supported by bootstrapping. Although the node joining the 123rd genotype and the other genotypes had a significant bootstrap value (96\%) (Fig. 3), the other nodes had values of 0 to $46 \%$ (data not shown). The frequency distribution of the 123 genotypes among the 359 isolates also is shown in Figure 3.

Analyses of the sample populations from South America and Japan using AFLP-based lineage and genotype. We tested the similarity frequency of distributions of the seven lineages among $C$. kikuchii isolates by performing $\chi^{2}$ tests. The frequency distribution of lineages of South American isolates was significantly different from that of total Japanese isolates, thiophanatemethyl-sensitive isolates, and resistant isolates from Japan (Table 2 ). The lineage diversity of the South American population based on the Shannon-Weaver's $(H w)$ and the Simpson's $(\lambda)$ indices was not significantly different from those of the Japanese population and subpopulations, but was significantly higher than that of the subpopulation resistant to thiophanate-methyl (Table 2). ShannonWeaver's diversity index has been used most frequently in the estimation of population diversity (14); Simpson's diversity index represents the probability that two individuals randomly chosen from a sample will belong to different groups.

To determine whether the frequency of lineage I differed among populations, we combined the number of isolates in lineages II to VII and carried out the $\chi^{2}$ tests. The frequency distribution of isolates in lineage I and combined lineages II to VII from South America was not significantly different from the Japanese isolates, except for the isolates resistant to thiophanate-methyl (Table 3 ). The genotype diversity of the South American lineage I population was significantly lower than those of the Japanese lineage I population and lineage I subpopulations, except for the lineage I subpopulation resistant to thiophanate-methyl (Table 3).

\section{DISCUSSION}

Cluster analyses of the DNA fingerprint patterns based on AFLP and the $\beta$-tubulin gene nucleotide sequence polymorphisms revealed that the sample population of $C$. kikuchii from South America was composed of five lineages. Of the 160 isolates, 136 isolates belonged to a single lineage, suggesting that the lineage was dominant. In the previous study, we found four lineages (I to IV) based on AFLP using the primer pair EcoRI-C/MseI-TC among the $C$. kikuchii isolates from Japan; lineage I was the largest of the four lineages (22). In the present study, we further confirmed the division into four lineages and the dominance of lineage I by using the primer pair EcoRI-A/MseI-CA in addition to EcoRI-C/MseI-TC. Comparison of the genotype structure of populations from South America and Japan revealed that lineages I and III commonly existed in the two areas; lineages II and IV

TABLE 2. Frequency distribution of the seven amplified fragment length polymorphism (AFLP) lineages among Cercospora kikuchii isolates belonging to South American and Japanese populations ${ }^{\mathrm{a}}$

\begin{tabular}{|c|c|c|c|c|c|c|c|c|c|c|c|c|}
\hline \multirow[b]{3}{*}{ Population $^{b}$} & \multicolumn{8}{|c|}{ Number of isolates } & & & & \\
\hline & \multirow[b]{2}{*}{ Total } & \multicolumn{7}{|c|}{ AFLP lineages } & \multicolumn{2}{|c|}{$\chi^{2}$ test $^{\mathrm{c}}$} & \multicolumn{2}{|c|}{ Lineage diversity $^{\mathrm{d}}$} \\
\hline & & I & II & III & IV & $\mathrm{V}$ & VI & VII & df & $\chi^{2}$ value & $H w$ & $\lambda$ \\
\hline South America & 160 & 136 & 0 & 5 & 0 & 3 & 1 & 15 & $\ldots$ & & 0.57 & 0.27 \\
\hline Japan & 245 & 223 & 12 & 8 & 2 & 0 & 0 & 0 & 6 & $38.64 * * * * *$ & $0.38^{\text {ns }}$ & $0.17^{\mathrm{ns}}$ \\
\hline Sensitive & 93 & 71 & 12 & 8 & 2 & 0 & 0 & 0 & 6 & $39.10 * * * * *$ & $0.76^{\mathrm{ns}}$ & $0.40^{\mathrm{ns}}$ \\
\hline Resistant & 152 & 152 & 0 & 0 & 0 & 0 & 0 & 0 & 4 & $24.7 * * * *$ & $0.00 * * * * *$ & $0.00 * * * * *$ \\
\hline
\end{tabular}

a Significance: $\mathrm{ns}=$ not significant, $* * * *=P<0.0001$, and $* * * * *=P<0.00001$.

b All South American isolates tested were sensitive to thiophanate-methyl. In Japan, subpopulations were sensitive or resistant to thiophanate-methyl.

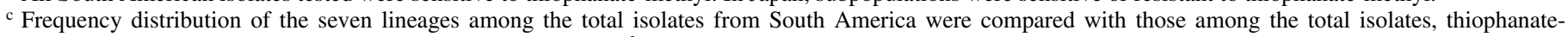
methyl-sensitive isolates, and resistant isolates from Japan by $\chi^{2}$ test.

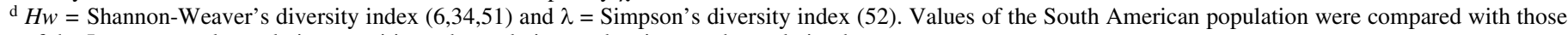
of the Japanese total population, sensitive subpopulation, and resistant subpopulation by $t$ test. 
Number of isolates

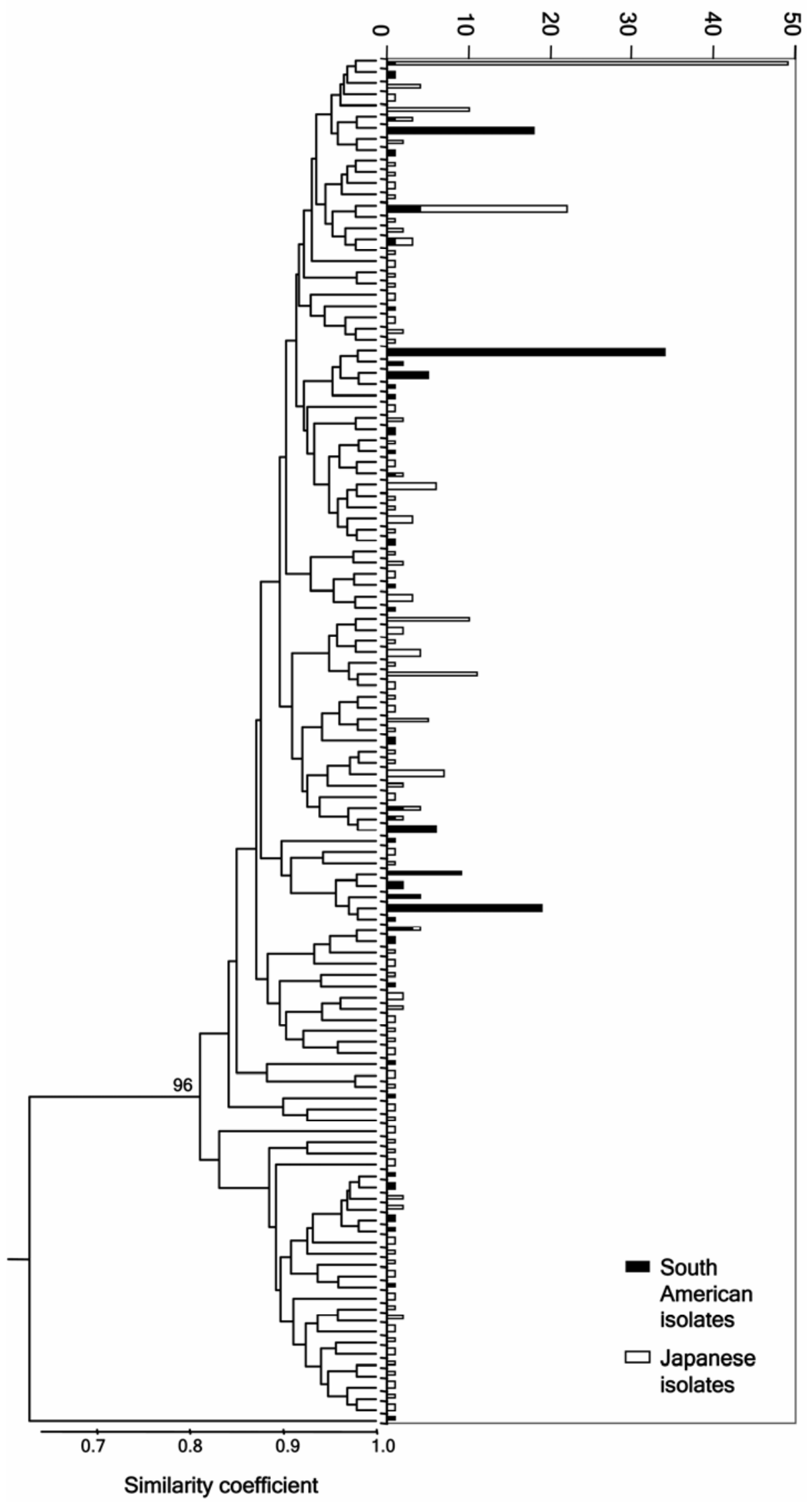

Fig. 3. Phenogram showing levels of similarity among the 359 Cercospora kikuchii isolates belonging to lineage I. Similarity coefficients were calculated from genotype data based on amplified fragment length polymorphism fingerprint patterns. The phenogram was constructed from the similarity coefficient by means of unweighted pairgroup method with arithmetic mean clustering. Scale bar indicates the similarity between clusters. Value on the branch of the phenogram represents the percent appearance of the given branch in 200 bootstrap replications. Graph represents the number of isolates belonging to each of 123 genotypes. 
TABLE 3. Characteristics of lineage I populations of Cercospora kikuchii ${ }^{\mathrm{a}}$

\begin{tabular}{|c|c|c|c|c|c|c|}
\hline \multirow[b]{2}{*}{ Population } & \multicolumn{2}{|c|}{ Number of isolates } & \multicolumn{2}{|c|}{$\chi^{2}$ test $^{b}$} & \multicolumn{2}{|c|}{ Genotype diversity $^{\mathrm{c}}$} \\
\hline & I & II to VII & $\mathrm{df}$ & $\chi^{2}$ value & $H w$ & $\lambda$ \\
\hline South America & 136 & 24 & $\ldots$ & $\ldots$ & 2.82 & 0.89 \\
\hline Japan & 223 & 22 & 1 & $3.48^{\mathrm{ns}}$ & $3.7 * * * * *$ & $0.94 *$ \\
\hline Sensitive & 71 & 22 & 1 & $2.96^{\mathrm{ns}}$ & $3.82 * * * * *$ & $0.99 * * * * *$ \\
\hline Resistant & 152 & 0 & 1 & $24.70 * * * * *$ & $2.95^{\mathrm{ns}}$ & $0.88^{\mathrm{ns}}$ \\
\hline
\end{tabular}

a Significance: $\mathrm{ns}=$ not significant, $*=P<0.05$, and $* * * * *=P<0.00001$.

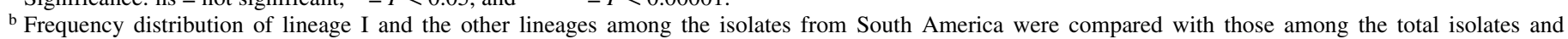
thiophanate-methyl-sensitive and -resistant isolates from Japan by $\chi^{2}$ test.

${ }^{c}$ Values of the lineage I South American population were compared with those of the Japanese population and subpopulations by $t$ test.

specifically existed in Japan; and three lineages, named lineages V to VII, specifically existed in South America. The difference in the frequency distribution of the seven lineages among C. kikuchii isolates between the two areas was supported by the $\chi^{2}$ test. These results suggest that the genetic structure of the $C$. kikuchii populations between the two areas is different.

We divided the sample isolates into seven lineages based on AFLP similarity and bootstrap significance levels. Lineages I, II, III, IV, V, and VII were joined by a single node at $0.69,0.71$, $0.68,0.83,0.90$, and 0.68 similarity levels, respectively. Of the six lineages, the four lineages I, II, III, and VII, that consisted of several genotypes, showed 0.68 to 0.71 similarity levels. Thus, we suggest that genotypes belonging to the same lineage may be joined by a single node at approximately 0.70 similarity levels if the AFLP markers are used. The $\beta$-tubulin gene nucleotide sequence polymorphisms divided the sample isolates into the 12 forms corresponding to AFLP lineages. However, the $\beta$ tubulin gene nucleotide sequence polymorphisms had a lower resolution than AFLP. For example, focusing on lineage VII, we could find 10 genotypes by AFLP but only 2 forms by the $\beta$ tubulin gene.

Selection is the most important evolutionary process in relation to fungicide resistance, because the strength of selection generally overrides random events (37). In a previous study, we found that a single thiophanate-methyl application increased the isolation frequency of resistant strains of C. kikuchii and reduced the genotype diversity of a sample population (21). Thus, genetic structure may be affected by application of the fungicide if resistant strains are present. We found isolates resistant to thiophanate-methyl in the population from Japan, suggesting that its genetic structure was affected by selection pressure from the fungicide. In contrast, the genetic structure of the South American population may be a result of random events. To remove this potential bias, we separated the sensitive and resistant subpopulations. The results of analyses using the sensitive subpopulation supported those using the total population.

Our results suggest that the genotype diversity of the lineage I population from South America is lower than that from Japan. Shannon-Weaver's diversity index is affected by sample size (14); therefore, the smaller total South American sample size meant that we could not be sure that the South American diversity was lower than the Japanese diversity. To get around this problem, we also compared the thiophanate-methyl-sensitive subpopulations, among which the South American sample size was larger, to compare genotype diversity. This comparison also showed that the lineage I population from South America had a lower genotype diversity. In addition, no difference in lineage diversity of the populations between South America and Japan could be supported by the comparison with the thiophanate-methyl sensitivesubpopulation.

Comparisons between sexual and asexual populations of the same species of fungi invariably show that sexual populations have a greater diversity of genotypes (36). Thus, sexual reproduction thus thought to be a cause of genotype diversity (8). C. kikuchii is known to be an asexual fungus, as supported by the division into lineages. Thus, the difference in genotype diversity of the lineage I populations between the two areas is not attributable to sexual reproduction.

We hypothesized that C. kikuchii was introduced directly or indirectly into South America from eastern Asia on soybean seed, because purple stain is a typical seedborne disease (50). Lineages I and III commonly existed in the two areas, which may support our hypothesis. We supposed that conidia of C. kikuchii are not frequently dispersed between South America and Japan, because we found that the isolation frequency of lineages I to VII in each area are significantly different, the areas are approximately $20,000 \mathrm{~km}$ apart and are separated by oceans, and the genotype diversity of the lineage I populations was distinctive between the areas. According to the interpretation of the introduction of C. kikuchii into South America from Japan or nearby, the lower genotype diversity of the lineage I population in South America than that in Japan might be attributable to the founder effect. To confirm this hypothesis further, we are collecting $C$. kikuchii isolates in China to compare those with the sample in the present study.

Of the total isolates from South America and Japan, 85 and $91 \%$, respectively, belonged to lineage I; there was no significant geographical differentiation in the frequency of lineage I isolates between the two areas. One of our next aims will be to investigate the causes of the dominance of lineage I.

\section{ACKNOWLEDGMENTS}

We thank K. Takahashi (National Agricultural Research Center) for organizing our collaborative research; S. Kawasaki (National Institute for Agrobiological Sciences) for technical assistance in AFLP analyses; $\mathrm{H}$. Suga (Gifu University) for help on population biological analyses; M. Hasegawa (Tottori Agricultural Experimental Station), K. Inoue (Okayama Prefecture General Agriculture Center), T. Iwama (Aomori Prefectural Agriculture and Forestry Research Center), K. Katsube (Iwate Agricultural Research Center), H. Mukobata (Toyama Agricultural Research Center), Y. Monma (Miyagi Prefectural Government Industry Department), J. Moriwaki (National Agricultural Research Center), Y. Murakami (Ehime Agricultural Experiment Station), N. Sakamoto (Aomori Prefectural Agriculture and Forestry Research Center), I. Shigemori (Nagano Chushin Agricultural Experiment Station), K. Watanabe (Ibaraki Agricultural Center), K. Yagasaki (Saitama Prefecture General Agricultural Research Center), J. Yamaguchi (Saga Agricultural Exprimental Research Center), and H. Yoshimatsu (Oita Prefectural Agricultural Research Center) for providing the diseased soybean seed and C. kikuchii isolates; and N. Yasuda and A. Kawakami (National Agricultural Research Center) for valuable suggestions.

\section{LITERATURE CITED}

1. Adachi, Y., Watanabe, H., Tanabe, K., Doke, N., Nishimura, S., and Tsuge, T. 1993. Nuclear ribosomal DNA as a probe for genetic variability in the Japanese pear pathotype of Alternaria alternata. Appl. Environ. Microbiol. 59:3197-3205.

2. Albertini, C., Gredt, M., and Leroux, P. 1999. Mutations of the $\beta$-tubulin gene associated with different phenotypes of benzimidazole resistance in the cereal eyespot fungi Tapesia yallundae and Tapesia acuformis. Pestic. Biochem. Physiol. 64:17-31. 
3. Bagley, M. J., Anderson, S. L., and May, B. 2001. Choice of methodology for assessing genetic impacts of environmental stressors: Polymorphism and reproducibility of RAPD and AFLP fingerprints. Ecotoxicology 10:239-244.

4. Becker, J. Vos, P., Kuiper, M., Salamini, F., and Heun, M. 1995. Combined mapping of AFLP and RFLP markers in barley. Mol. Gen. Genet. 249:65-73.

5. Bonetti, L. P. 1981. Origem, história e distribuição. Pages 1-6 in: A Soja no Brasil. S. Miyasaka, and J. C. Medina, eds. Institute de Technologia de Alimentos-ITAL, Campinas, Brazil. In Portuguese.

6. Brower, J. E., Zar, J. H., and von Ende, C. N. 1998. Field and Laboratory Methods for General Ecology. McGraw-Hill, Boston.

7. Brown, J. K. M., and Hovmфller, M. S. 2002. Aerial dispersal of pathogens on the global and continental scales and its impact on plant disease. Science 297:537-541.

8. Drenth, A., Tas, I. C. Q., and Govers, F. 1994. DNA fingerprinting uncovers a new sexually reproducing population of Phytophthora infestans in the Netherlands. Eur. J. Plant Pathol. 100:97-107.

9. Dunkle, L. D., and Levy, M. 2000. Genetic relatedness of African and United States populations of Cercospora zeae-maydis. Phytopathology 90:486-490.

10. Felsenstein, J. 1985. Confidence limits on phylogenies: An approach using the bootstrap. Evolution 39:783-791.

11. Friesen, T. L., Ali, S., Klein, K. K., and Rasmussen, J. B. 2005. Population genetic analysis of a global collection of Pyrenophora triticirepentis, causal agent of tan spot of wheat. Phytopathology 95:1144-1149.

12. Gordon, T. R., and Martin, R. D. 1997. The evolutionary biology of Fusarium oxysporum. Annu. Rev. Phytopathol. 35:111-128.

13. Goto, K. 2001. Origin of cultivation and distribution. Pages 33-41 in: Soybean Adzuki Bean. Rural Culture Association, ed. Rural Culture Association, Tokyo. In Japanese.

14. Grünwald, N. J., Goodwin, S. B., Milgoom, M. G., and Fry, W. E. 2003. Analysis of genotypic diversity data for populations of microorganisms. Phytopathology 93:738-746.

15. Hamelin, R. C., Lecours, N., and Laflamme, G. 1998. Molecular evidence of distinct introductions of the European race of Gremmeniella abietina into North America. Phytopathology 88:582-588.

16. Higgins, D. G., Thompson, J. D., and Gibson, T. J. 1996. Using CLUSTAL for multiple sequence alignments. Methods Enzymol. 266:383-402.

17. Howard, R. J., and Aist, J. R. 1977. Effects of MBC on hyphal tip organization, growth, and mitosis of Fusarium acuminatum, and their antagonism by $\mathrm{D}_{2} \mathrm{O}$. Protoplasma 92:195-210.

18. Howard, R. J., and Aist, J. R. 1980. Cytoplasmic microtubules and fungal morphogenesis: Ultrastructural effects of methyl benzimidazole-2-yl carbamate determined by freeze-substitution of hyphal tip cells. J. Cell Biol. 87:55-64.

19. Hymowitz, T. 1995. Soybean. Pages 261-265 in: Evolution of Crop Plants, 2nd ed. J. Smartt and N. W. Simmonds, eds. Longman Scientific and Technical, Essex, England.

20. Hymowitz, T., Nelson, R. L., Sinclair, J. B., and Hartman, G. L. 1999. History and growth of the soybean plant. Pages 1-3 in: Compendium of Soybean Diseases, 4th ed. G. L. Hartman, J. B. Sinclair, and J. C. Rupe, eds. The American Phytopathological Society, St. Paul, MN.

21. Imazaki, I., Iizumi, H., Ishikawa, K., Sasahara, M., Yasuda, N., and Koizumi, S. 2006. Effects of thiophanate-methyl and azoxystrobin on the composition of Cercospora kikuchii populations with thiophanate-methylresistant strains. J. Gen. Plant Pathol. 72:292-300.

22. Imazaki, I., Ishikawa, K., Yasuda, N., Miyasaka, A., Kawasaki, S., and Koizumi, S. 2006. Incidence of thiophanate-methyl resistance in Cercospora kikuchii within a single lineage based on amplified fragment length polymorphisms in Japan. J. Gen. Plant Pathol. 72:77-84.

23. Inoue, I., Ishikawa, K., Yasuda, N., Miyasaka, A., and Koizumi, S. 2004. Genetic structure of benzimidazole-resistant population of the soybean purple stain fungus Cercospora kikuchii in Japan. (Abstr.) Phytopathology 94(suppl.):S44

24. Ishii, H. 2001. DNA-based approaches for diagnosis of fungicide resistance. Pages 242-259 in: Agrochemical Resistance: Extent, Mechanisms, and Detection. J. M. Clark and I. Yamaguchi, eds. American Chemical Society, Washington DC

25. Janssen, P., Coopman, R., Huys, G., Swings, J. Bleeker, M., Vos, P., Zabeau, M., and Kersters, K. 1996. Evaluation of the DNA fingerprinting method AFLP as a new tool in bacterial community. Microbiology 142:1881-1893.

26. Jones, C. J., Edwards, K. J., Castaglione, S., Winfield, M. O., Sala, F., van de Wiel, C., Bredemeijer, G., Vosman, B., Matthes, M., Daly, A., Brettschneider, R., Bettini, P., Buiatti, M., Maestri, E., Malcevschi, A., Marmiroli, N., Aert R., Volckaert, G., Rueda, J., Linacero, R., Vazquez A., and Karp, A. 1997. Reproducibility testing of RAPD, AFLP and SSR markers in plants by a network of European laboratories. Mol. Breed. 3:381-390
27. Jukes, T. H., and Cantor, C. R. 1969. Evolution of protein molecules. Pages 21-132 in: Mammalian Protein Metabolism. H. N. Munro, ed. Academic Press, New York.

28. Kasanen, R., Hantula, J., Ostry, M., Pinon, J., and Kurkela, T. 2004. North American populations of Entoleuca mammata are genetically more variable than populations in Europe. Mycol. Res. 108:766-774.

29. Katsube, T. 1980. Effects of Cercospora kikuchii disease on plant growth, seed yield, and contents of proteins, lipids, and carbohydrates in seeds. Annu. Rep. Plant Prot. N. Jpn. 31:64-66. In Japanese.

30. Koenraadt, H., Somerville, S. C., and Jones, A. L. 1992. Characterization of mutants in the beta-tubulin gene of benomyl-resistant field strains of Venturia inaequalis and other plant pathogenic fungi. Phytopathology 82:1348-1354.

31. Kumar, S., Tamura, K., and Nei, M. 2004. MEGA3: Integrated software for molecular evolutionary genetics analysis and sequence alignment. Brief. Bioinform. 5:150-163.

32. Lehman, S. G. 1950. Purple stain of soybean seeds. North Carolina State Agric. Stn. Bull. 369:1-11

33. Lin, J. J., Kuo, J., Ma, J., Saunders, J. A., Beard, H. S., Macdonald, M. H., Kenworthy, W., Ude, N., and Matthews, F. 1996. Identification of molecular markers in soybean comparing RFLP, RAPD, and AFLP DNA mapping techniques, Plant Mol. Biol. Rep. 14:156-159.

34. Magurran, A. E. 1988. Ecological Diversity and its Measurement. Princeton University Press, Princeton, NJ.

35. Majer, D., Lewis, B. G., and Mithen, R. 1998. Genetic variation among field isolates of Pyrenopeziza brassicae. Plant Pathol. 47:22-28.

36. Milgroom, M. G. 1996. Recombination and the multilocus structure of fungal populations. Annu. Rev. Phytopathol. 34:457-477.

37. Milgroom, M. G., Levin, S. A., and Fry, W. E. 1989. Population genetic theory and fungicide resistance. Pages 340-367 in: Plant Disease Epidemiology, Vol. 2. K. J. Leonard and W. E. Fry, eds. McGraw-Hill, New York

38. Milgroom, M. G., Wang, K., Zhou, Y., Lipari, S. E., and Kaneko, S. 1996. Intercontinental population structure of the chestnut blight fungus, Cryphonectria parasitica. Mycologia 88:179-190.

39. Miller, W. A., and Roy, K. W. 1982. Effects of benomyl on the colonization of soybean leaves, pods, and seeds by fungi. Plant Dis. 66:918-920.

40. Monma Y., Ishii, H., Koizumi, S., Koike, N., Sasahara, M., Yasuda, N., and Miyasaka, A. 2003. Molecular analysis of benzimidazole resistance in soybean purple stain fungus and testing its fungicide sensitivity using host seedlings. (Abstr.) Jpn. J. Phytopathol. 69:299.

41. Murakishi, H. H. 1951. Purple seed stain of soybeans. Phytopathology 41:305-318

42. Nagata, T. 1959. Studies on the differentiation of soybeans in the world, with special regard to that in Southeast Asia. Proc. Crop Sci. Soc. Jpn. 28:79-82.

43. O'Donnell, K., Kistler, H. C., Tacke, B. K., and Casper, H. H. 2000. Gene genealogies reveal global phylogeographic structure and reproductive isolation among lineages of Fusarium graminearum, the fungus causing wheat scab. Proc. Natl. Acad. Sci. USA 97:7905-7910.

44. Pasquali, M., Dematheis, F., Gilardi, G., Gullino, M. L., and Garibaldi, A. 2005. Vegetative compatibility groups of Fusarium oxysporum f. sp. lactucae from lettuce. Plant Dis. 89:237-240.

45. Piper, C. V., and Morse, W. J. 1923. The Soybean. McGraw-Hill Book Company, New York.

46. Qiu, L., Chang, R., Sun, J., Li, X., Cui, Z., and Li, Z. 1999. The history and use of primitive varieties in Chinese soybean breeding. Pages 165172 in: World Soybean Research Conference VI: Proceedings. H. E. Kauffman, ed. Superior Printing, Champaign, IL.

47. Reyes, G., and Ghannoum, M. A. 2000. Antifungal susceptibility testing of yeasts: Uses and limitations. Drug Resist. Updates 3:14-19.

48. Rosewich, U. L., Pettway, R. E., Katan, T., and Kistler, H. C. 1999. Population genetic analysis corroborates dispersal of Fusarium oxysporum f. sp. radicis-lycopersici from Florida to Europe. Phytopathology 89:623630.

49. Sakai, Y. 1999. Optimum timing of thiophanate-methyl application in the control of purple stain on soybean seed with consideration of development of resistance. Ann. Phytopathol. Soc. Jpn. 65:510-514.

50. Schuh, W. 1999. Cercospora blight, leaf spot, and purple seed stain. Pages 17-18 in: Compendium of Soybean Diseases, 4th ed. G. L. Hartman, J. B. Sinclair, and J. C. Rupe, eds. The American Phytopathological Society, St. Paul, MN.

51. Shannon, C. E., and Weaver, W. 1949. The Mathematical Theory of Communication. University of Illinois Press, Urbana, IL.

52. Simpson, E. H. 1949. The measurement of diversity. Nature 163:688

53. Smith, K. J., and Huyser, W. 1987. World distribution and significance of soybean. Pages 1-22 in: Soybeans: Improvement, Production, and Uses, 2nd ed. J. R. Wilcox, ed. American Society of Agronomy, Crop Science Society of America, and Soil Science Society of America, Madison, WI. 
54. Sneath, P. H. A., and Sokal, R. R. 1973. Numerical Taxonomy. Freeman, San Francisco.

55. Sokal, R. R., and Michener, C. D. 1958. A statistical method for evaluating systematic relationship. Univ. Kans. Sci. Bull. 28:1409-1438.

56. Sunada, K. 1977. History. Pages 34-38 in: Cultivars of Beans in Hokkaido. Editorial Committee on Cultivars of Beans in Hokkaido, ed. Japan Beans and Peas Foundation, Tokyo. In Japanese.

57. TeKrony, D. M., and Egli, D. B. 1985. Effect of benomyl applications on soybean seedborne fungi, seed germination, and yield. Plant Dis. 69:763765.

58. Thompson, J. D., Higgins, D. G., and Gibson, T. J. 1994. CLUSTAL W: Improving the sensitivity of progressive multiple sequence alignment through sequence weighting, positions-specific gap penalties and weight matrix choice. Nucleic Acids Res. 22:4673-4680.

59. Vos, P., Hogers, R., Bleeker, M., Reijans, M., van de Lee, T., Hornes, M., Frijters, A., Pot, J., Peleman, J., Kuiper, M., and Zabeau, M. 1995. AFLP: A new technique for DNA fingerprinting. Nucleic Acids Res. 23:44074414.

60. Wang, J., Levy, M., and Dunkle, L. D. 1998. Sibling species of Cercospora associated with gray leaf spot of maize. Phytopathology 88:1269-1275.

61. Wilcox, J. R. 2004. World distribution and trade of soybean. Pages 1-14 in: Soybeans: Improvement, Production, and Uses, 3rd ed. H. R. Boerma and J. E. Specht, eds. American Society of Agronomy, Crop Science Society of America, and Soil Science Society of America, Madison, WI.

62. Wilcox, J. R., and Abney, T. S. 1973. Effects of Cercospora kikuchii on soybeans. Phytopathology 63:796-797.

63. Williams, G. W., and Thompson, R. L. 1985. The South American soybean industry: Policy impacts and issues. Pages 49-56 in: World Soybean Research Conference III: Proceedings. R. Shibles, ed. Westview Press, Boulder, CO.

64. Yap, I. V., and Nelson, R. J. 1996. Winboot: A program for performing bootstrap analysis of binary data to determine confidence limits of UPGMA-based dendrograms. Int. Rice Res. Inst. Dis. Paper Ser. 14, Manila, Philippines.

65. Yarden, O., and Katan, T. 1993. Mutations leading to substitutions at amino acids 198 and 200 of beta tubulin that correlate with benomylresistance phenotypes of field strains of Botrytis cinerea. Phytopathology 83:1478-1483.

66. Zhan, J., Pettway, R. E., and McDonald, B. A. 2003. The global genetic structure of the wheat pathogen Mycosphaerella graminicola is characterized by high nuclear diversity, low mitochondrial diversity, regular recombination, and gene flow. Fungal Genet. Biol. 38:286-297. 